University of Nebraska - Lincoln

DigitalCommons@University of Nebraska - Lincoln

Agronomy \& Horticulture -- Faculty Publications

Agronomy and Horticulture Department

2004

\title{
Using Multi-Spectral Imagery To Evaluate Corn Grown Under Nitrogen and Drought Stressed Conditions
}

\author{
Shannon L. Osborne \\ University of Nebraska-Lincoln, sosborne@ngirl.ars.usda.gov \\ James S. Schepers \\ USDA-ARS, Soil and Water Conservation Research Unit, james.schepers@gmail.com \\ Mike R. Schlemmer \\ USDA-ARS, Soil and Water Conservation Research Unit, East Campus Lincoln, Nebraska, USA
}

Follow this and additional works at: https://digitalcommons.unl.edu/agronomyfacpub

Part of the Agricultural Science Commons, Agriculture Commons, Agronomy and Crop Sciences Commons, Botany Commons, Horticulture Commons, Other Plant Sciences Commons, and the Plant Biology Commons

Osborne, Shannon L.; Schepers, James S.; and Schlemmer, Mike R., "Using Multi-Spectral Imagery To Evaluate Corn Grown Under Nitrogen and Drought Stressed Conditions" (2004). Agronomy \& Horticulture -- Faculty Publications. 825.

https://digitalcommons.unl.edu/agronomyfacpub/825

This Article is brought to you for free and open access by the Agronomy and Horticulture Department at DigitalCommons@University of Nebraska - Lincoln. It has been accepted for inclusion in Agronomy \& Horticulture -Faculty Publications by an authorized administrator of DigitalCommons@University of Nebraska - Lincoln. 


\title{
Using Multi-Spectral Imagery To Evaluate Corn Grown Under Nitrogen and Drought Stressed Conditions
}

\author{
Shannon L. Osborne, ${ }^{1, *}$ James S. Schepers, ${ }^{2}$ \\ and Mike R. Schlemmer ${ }^{2}$ \\ ${ }^{1}$ Department of Agronomy, University of Nebraska, Lincoln, \\ Nebraska, USA \\ ${ }^{2}$ USDA-ARS, Soil and Water Conservation Research Unit, \\ East Campus Lincoln, Nebraska, USA
}

\begin{abstract}
The in-season estimation of crop stresses which have the potential of adversely affecting crop yield and/or quality could allow producers to make in-season management decisions to correct for the particular stress. A field study was conducted to evaluate the use of multispectral imagery for estimating corn (Zea mays L.) grain yield, in-season biomass and nitrogen $(\mathrm{N})$ concentration under varying $\mathrm{N}$ and drought stresses. The experiment was a split-plot design with three replications using a factorial arrangement of treatments. Three
\end{abstract}

*Correspondence: Shannon L. Osborne, USDA-ARS, Northern Grains Insects Research Laboratory, 2923 Medary Ave., Brookings, SD 57006, USA; E-mail: sosborne@ngirl.ars.usda.gov.

DOI: 10.1081/LPLA-200030042

Copyright (c) 2004 by Marcel Dekker, Inc.
0190-4167 (Print); 1532-4087 (Online) www.dekker.com

This document is a U.S. government work and 
irrigation (whole-plot) treatments included dry land, irrigation based on 0.5 , and full evapotranspiration (ET). Sub-plot treatments included five $\mathrm{N}$ rates $\left(0,45,90,134,269 \mathrm{~kg} \mathrm{Nha}^{-1}\right)$. Multi-spectral imagery consisted of four wavebands; blue $(485 \mathrm{~nm} \pm 35 \mathrm{~nm})$, green $(550 \mathrm{~nm} \pm 35 \mathrm{~nm})$, red $(660 \mathrm{~nm} \pm 30 \mathrm{~nm})$, and near-infrared (NIR) $(830 \mathrm{~nm} \pm 70 \mathrm{~nm})$. Imagery was collected on various dates throughout the growing season; biomass sampling was performed within two days of image collection. Grain yield, in-season biomass, and $\mathrm{N}$ concentration increased with increasing $\mathrm{N}$ rate regardless of sampling date or year. Yield was only affected by irrigation during 1997 due to a significant difference in rainfall between 1997 and 1998, 247 vs. $457 \mathrm{~mm}$, respectively. Regression correlation coefficients for the 1998 values were generally higher compared to 1997 values across years for imagery collected at similar growth stages, possibly due to differences in sensor sensitivity or the increased plant response to applied N. Regression correlation coefficients increased as the growing season progressed. The green waveband and normalized difference greenness vegetation index (GNDVI) had the greatest ability to estimate grain yield in the presence of varying $\mathrm{N}$ and/or drought stresses. This study demonstrates the ability of multispectral imagery analysis to estimate grain production in the presence of $\mathrm{N}$ and/or drought stresses.

\section{INTRODUCTION}

Adoption of precision agriculture or site-specific management would be enhanced by the ability to identify yield-limiting factors during the growing season. Available water and $\mathrm{N}$ are critical yield limiting factors in corn production. Real-time identification of these stresses could be beneficial to producers making various in-season management decisions. Remote sensing technologies have the potential to be utilized in this manner for assessing in-season stresses. Remote sensing is defined as obtaining information about an object, area, or phenomenon by analyzing data acquired from a device that is not in contact with the object, area, or phenomenon. ${ }^{[1]}$ There are many ways to obtain remotely sensed data, including aerial photography, satellite images, hand held radiometers, or aircraft mounted sensors. These systems are either hyperspectral or multi-spectral in nature. A hyper-spectral system is defined as collecting data in numerous segments placed continuously throughout a defined portion of the spectrum. ${ }^{[1]}$ A multi-spectral system is defined as collecting data in a few unique portions but not continuously throughout the spectrum. ${ }^{[1]}$ 
Numerous studies evaluate the potential of multi-spectral remote sensing to characterize vegetation parameters, but the majority of these have been performed on a large scale (landscape, characterizing an entire field, etc.). These studies have focused on evaluating indices (combinations of individual wavebands) to estimate various parameters. The most widely used index is the normalized difference vegetation index (NDVI) developed by Tucker. ${ }^{[2]}$ The NDVI is correlated with a number of different vegetation parameters such as leaf area, biomass, and percent cover. ${ }^{[3,4]}$ Using hand-held or vehicle mounted hyper-spectral systems to measure reflectance, researchers have collected reflectance data corresponding to similar wavebands available in satellite-sensed data. Kleman and Fagerlund ${ }^{[5]}$ investigated wavebands that are present on the Landsat multi-spectral scanner (MSS) using a radiometer measuring 400 to $2300 \mathrm{~nm}$. They found that a NIR $(800 \mathrm{~nm})$ to red $(680 \mathrm{~nm})$ ratio was highly correlated to total shoot biomass for barley (Hordeum L.) in the early growth stages. A reflectance ratio of $800: 1650 \mathrm{~nm}$ was better for biomass estimation at later growth stages and for estimating grain yield. They noted that reflectance in the blue region of the spectrum was strongly related to different irrigation levels, but was insensitive to the amount of biomass. A ratio of NIR to red reflectance could be used to estimate the amount of drought stress and the total amount of biomass present. Ahlrichs and Bauer ${ }^{[6]}$ found that variation in reflectance in the NIR band best explained leaf area index and percent soil cover while reflectance in the mid-infrared band explained differences in fresh biomass, dry biomass, and water content. Aase and Siddoway ${ }^{[7]}$ demonstrated a strong relationship between both grain yield and dry matter production with reflectance measurements taken at the same bandwidths of the Landsat MSS. They cautioned that there are many factors that can influence the readings such as hail damage, weed infestation, and disease incidence.

An alternative would be to utilize hyper-spectral systems to determine which particular wavelength is indicative of a particular stress. Reflectance in the green region in the visible portion of the electromagnetic spectrum has been established as a good indicator of $\mathrm{N}$ content in a number of different crops, including corn, wheat (Triticum aestivum L.), and bermudagrass [Cynodon dactylon (L.) Pers.]. ${ }^{[8-11]}$ Moran et al. ${ }^{[12]}$ investigated the effect of drought stress on the canopy architecture of alfalfa (Medicago sativa L.) and the sequential effect on canopy reflectance. They found that drought stressed canopies have a lower spectral reflectance in the NIR and red wavebands compared to unstressed canopies. A ratio of the two wavebands was most successful in estimating the onset of stress. 
While many researchers have investigated the relationship between wavelength combinations (indices) or reflectance at particular wavelengths with various vegetation parameters using satellite or aircraft based systems, few have collected intense ground truthing information on a small scale to verify relationships within a given field. This is partly due to the resolution at which satellite imagery is collected: 5 to $80 \mathrm{~m}^{2}$ depending on the satellite. Collecting ground truthing information on this scale could be very time consuming and costly. This could possibly require sampling across varying crop type, and management practices further complicating the verification. An alternative to this is to use imagery collected from aircraft based systems. Data collected using these systems can be at a resolution high enough to account for small variation within a field. This may enable a producer to make in-season management decisions that influence production on a field-by-field basis. The ability to utilize remotely sensed information in this manner could increase the adoption of remote sensing techniques in precision agricultural applications for correcting in-season nutrient or drought stresses, leading to greater yields. The objective of this research was to utilize high-resolution multi-spectral imagery for estimating in-season plant biomass, plant $\mathrm{N}$ concentration, grain yield, and grain $\mathrm{N}$ concentration in the presence and absence of $\mathrm{N}$ and/or drought stress.

\section{MATERIALS AND METHODS}

An irrigated continuous-corn experiment was conducted on a Hord silt loam (fine-silty, mixed, mesic Cumulic Haplustolls) located at the Management Systems Evaluation Area (MSEA) project site near Shelton, NE. Irrigation was applied using a linear drive irrigation system. Irrigation water contained less than $1 \mathrm{ppm}$ nitrate-N. Tillage was performed in late April with a disk, and cultivated in mid June when the plants were at approximately V5. Seeding rate was 74,000 plants $^{-1}$ with Pioneer brand hybrid 3489 planted on 5 May 1997 and 7 May 1998. The experimental design was a split-plot with three replications; treatments were arranged in a three by five factorial array, with the irrigation treatments applied to whole-plots and $\mathrm{N}$ rates to split-plots. The three irrigation treatments consisted of dry land (no additional irrigation except that needed to avoid complete crop loss) and irrigation based on 0.5 and full ET. Nitrogen treatments were applied as $\mathrm{NH}_{4} \mathrm{NO}_{3}$ at rates of $0,45,90,134$, and $269 \mathrm{~kg} \mathrm{~N} \mathrm{ha}^{-1}$. Nitrogen treatments were applied as a split application $1 / 2$ side-dress at V1-V2 and 1/2 side-dress at V4-V5 prior to cultivation. Starter fertilizer (13 $\mathrm{kg} \mathrm{Nha}^{-1}$ and $19 \mathrm{kgPha}^{-1}$ as ammonium polyphosphate) 
Table 1. Dates of irrigation and amount applied by irrigation treatment, Shelton, NE, 1997 and 1998.

\begin{tabular}{lccc}
\hline & Dryland & $0.5 \mathrm{ET}^{\mathrm{a}}$ & Full ET \\
\cline { 2 - 4 } Date & \multicolumn{3}{c}{$(\mathrm{mm})$} \\
\hline 30 June 1997 & 21.59 & 21.59 & 21.59 \\
9 July 1997 & 13.72 & 13.72 & 13.72 \\
10 July 1997 & - & 13.72 & 28.70 \\
15 July 1997 & - & - & 27.94 \\
18 July 1997 & - & 27.43 & 32.61 \\
23 July 1997 & - & - & 35.56 \\
30 July 1997 & 37.08 & 35.56 & 38.35 \\
8 Aug 1997 & - & 25.40 & 30.48 \\
29 June 1998 & - & - & 16.1 \\
3 July 1998 & - & - & 13.6 \\
21 July 1998 & - & - & 29.9 \\
22 Aug 1998 & - & - & 24.0 \\
5 Sept 1998 & - & 4.8 & 22.2 \\
\hline
\end{tabular}

${ }^{\mathrm{a}}$ ET-evapotranspiration.

was applied at planting. Plot size was $7.32 \times 22.86 \mathrm{~m}$ with $0.91 \mathrm{~m}$ row spacing. "Guardsman" [Dimethenamid (2-chloro- $N$-[(1-methyl-2-methoxy)ethyl]- $N$-(2,4-dimethyl-thien-3-yl)-acetamide] + Atrazine (2-chloro-4ethylamino-6-isopropyl-amino-s-trazine)] $53.1 \%$ active ingredient were applied to all plots at a rate of $3.5 \mathrm{~L} \mathrm{ha}^{-1}$ in early May. Individual irrigation rates and dates are reported in Table 1. Phenology data according to Ritchie et al. ${ }^{[13]}$ were recorded weekly from the first of June until the end of August and then bi-weekly until maturity.

Biomass sampling was performed throughout the growing season by taking 12 randomly selected plants from the east quarter of each plot. Whole plants were weighed and ears were separated once distinguishable. Whole plants were chopped with a chipper-shredder in the field to facilitate subsampling. Subsamples were weighed, oven dried at $50^{\circ} \mathrm{C}$, and then reweighed for water content. All samples were ground with a Wiley Mill to pass a $2 \mathrm{~mm}$ sieve. Nitrogen concentration was determined on all samples using dry combustion. ${ }^{[14]}$ Grain yield was estimated by hand harvesting $3.05 \mathrm{~m}$ from each of the four middle rows. Ears were shelled and water content determined. Grain samples were oven dried at $50^{\circ} \mathrm{C}$, ground, and analyzed as described above for biomass samples. Grain yield per plot was calculated and corrected to $155 \mathrm{~g} \mathrm{~kg}^{-1}$ moisture. 
Multi-spectral airborne imagery data, consisting of four bands; blue $(485 \pm 35)$, green $(550 \pm 35)$, red $(660 \pm 30)$, NIR $(830 \pm 70)$ were collected on various dates throughout the growing season. Imagery was obtained on cloud-free days at around solar noon, after which the imagery was downloaded and rectified to a $1-\mathrm{m}$ pixel resolution. The sensor system used to obtain imagery was 8-bit in 1997 and 12 bit in 1998. Thus the system was 16 times more sensitive in 1998 than 1997. Four $64 \mathrm{~m}^{2}$ calibration tarps of known reflectance characteristic for each band were visible in each image. Imagery was converted to percent reflectance for each band using the calibration tarps and indexed calculations such as GNDVI and NDVI. Pixel values were averaged for each plot to obtain an average reflectance value for each plot. Data for each plot were used to calculate NDVI and GNDVI.

$$
\begin{aligned}
& \text { NDVI }=\frac{\text { NIR }- \text { Red }}{\text { NIR }+ \text { Red }} \\
& \text { GNDVI }=\frac{\text { NIR }- \text { Green }}{\text { NIR }+ \text { Green }}
\end{aligned}
$$

Analysis of variance and least significant difference (Fisher protected LSD) tests were performed to assess $\mathrm{N}$ rate and irrigation effects on all plant biomass, plant $\mathrm{N}$ concentration, grain yield, and grain $\mathrm{N}$ concentration for each sampling date and year using the GLM procedure in SAS. ${ }^{[15]}$ Linear regression was utilized to develop regression coefficients for plant measurements with individual waveband and indexes using the REG procedure in SAS. ${ }^{[15]}$

\section{RESULTS AND DISCUSSION}

\section{In-season Biomass and Grain Harvest}

Analysis of variance performed on biomass, grain yield, and $\mathrm{N}$ concentrations did not reveal a significant interaction between $\mathrm{N}$ rate and irrigation treatment for any response measured or sampling date. Treatment means and mean separation for in-season biomass, plant $\mathrm{N}$, grain yield, and grain $\mathrm{N}$ concentrations are therefore reported in Tables 2 and 3 by sampling date. In general, grain yield, plant biomass, grain $\mathrm{N}$ concentration, and plant $\mathrm{N}$ concentration increased with increasing $\mathrm{N}$ rate (Tables 2 and 3). Late August samplings were the only ones to show effects on biomass production and $\mathrm{N}$ concentration from the different 
Table 2. In-season plant sampling treatment means and mean separation for biomass production and N concentration by sampling date, Shelton, NE, 1997 and 1998.

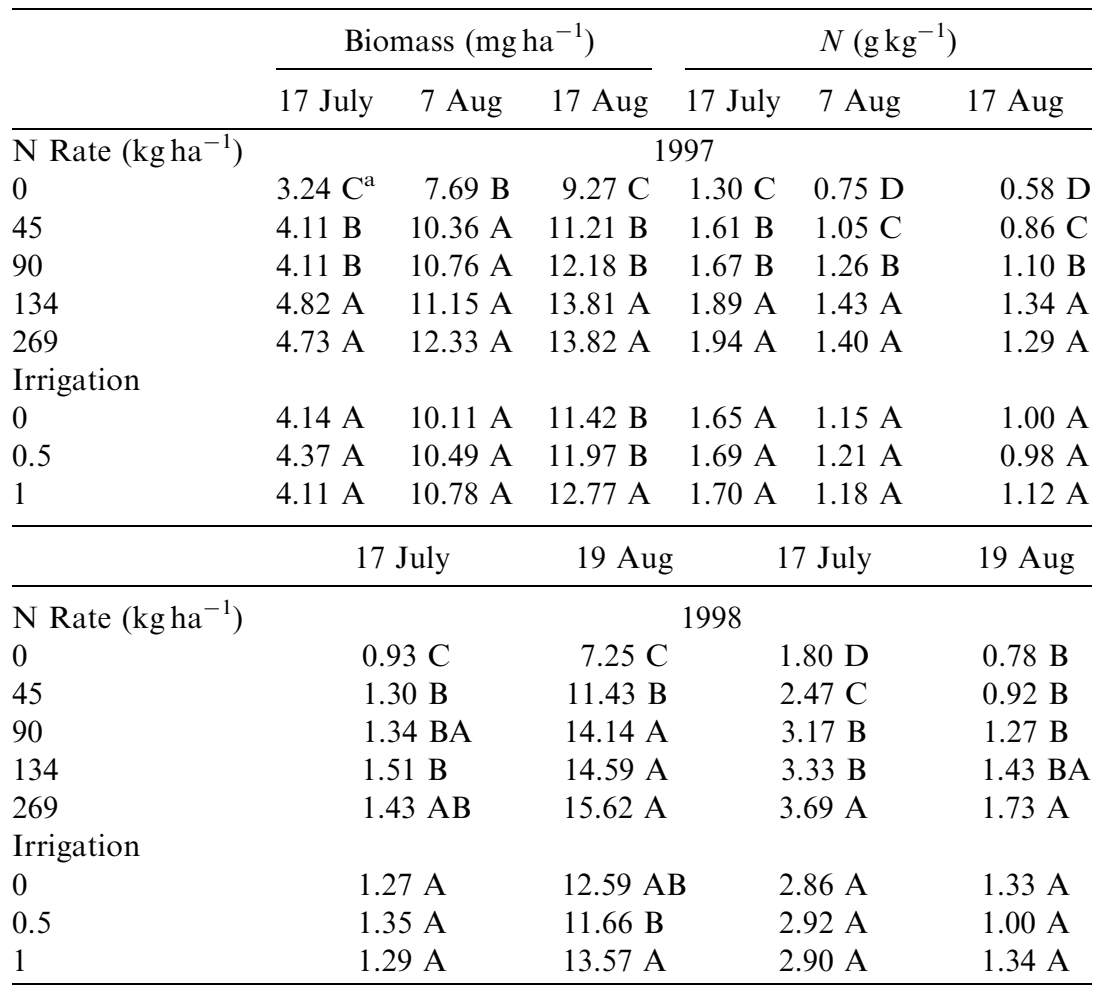

${ }^{a}$ Values in each category followed by the same letter are not significantly different at the 0.05 probability level according to a protected LSD test, calculated when overall $F$ values indicated significant variation among treatment means.

irrigation treatments (Table 2). This could have been due to the timing and amount of rainfall each year. Rainfall total for 1997 was only $247 \mathrm{~mm}$ compared to $457 \mathrm{~mm}$ in 1998; there was no rainfall during July and early August of 1997 (encompassing the end of the vegetative state and silking in the reproductive growth stage). During the 1998 growing season there was only a period of approximately one week around the middle of July when rainfall was inadequate; this did not affect biomass until the following sampling date. Due to this difference in rainfall there was only a measured drought stress (measured from canopy temperature and neutron probes, data not shown) prior to silking in 1997. This 
Table 3. Grain yield and $\mathrm{N}$ concentration means by main treatment effects and corresponding mean separation, Shelton, NE, 1997 and 1998.

\begin{tabular}{|c|c|c|c|c|}
\hline & \multicolumn{2}{|c|}{ Grain yield $\left(\mathrm{mg} \mathrm{ha}^{-1}\right)$} & \multicolumn{2}{|c|}{$\mathrm{N}\left(\mathrm{g} \mathrm{kg}^{-1}\right)$} \\
\hline & 1997 & 1998 & 1997 & 1998 \\
\hline \multicolumn{5}{|c|}{ N Rate $\left(\mathrm{kg} \mathrm{ha}^{-1}\right)$} \\
\hline 0 & $4.95 \mathrm{D}$ & $3.77 \mathrm{C}$ & $1.16 \mathrm{D}$ & $0.97 \mathrm{C}$ \\
\hline 45 & $7.69 \mathrm{C}$ & $6.14 \mathrm{~B}$ & $1.27 \mathrm{C}$ & $1.02 \mathrm{C}$ \\
\hline 90 & $9.09 \mathrm{~B}$ & $9.14 \mathrm{~A}$ & $1.43 \mathrm{~B}$ & $1.11 \mathrm{BC}$ \\
\hline 134 & $9.00 \mathrm{~B}$ & $9.79 \mathrm{~A}$ & $1.55 \mathrm{~A}$ & $1.20 \mathrm{~B}$ \\
\hline 269 & $10.00 \mathrm{~A}$ & $8.97 \mathrm{~A}$ & $1.59 \mathrm{~A}$ & $1.47 \mathrm{~A}$ \\
\hline \multicolumn{5}{|c|}{ Irrigation } \\
\hline 0 & $7.26 \mathrm{C}$ & $7.39 \mathrm{~A}$ & $1.51 \mathrm{~A}$ & $1.22 \mathrm{~A}$ \\
\hline 0.5 & $7.85 \mathrm{~B}$ & $7.44 \mathrm{~A}$ & $1.38 \mathrm{~B}$ & $1.13 \mathrm{~A}$ \\
\hline 1 & $9.32 \mathrm{~A}$ & $7.86 \mathrm{~A}$ & $1.32 \mathrm{~B}$ & $1.11 \mathrm{~A}$ \\
\hline
\end{tabular}

${ }^{\text {a }}$ Values in each category followed by the same letter are not significantly different at the 0.05 probability level according to a protected LSD test, calculated when overall $F$ values indicated significant variation among treatment means.

drought stress decreased yields by 22.1 and $15.8 \%$ for the dryland and $0.5 \mathrm{ET}$ irrigation treatments (averaged over all $\mathrm{N}$ treatments), respectively, compared to the full ET treatment in 1997 (Table 3). There was no significant difference among irrigation treatments in 1998.

\section{In-season Biomass Image Analysis}

Analysis of multi-spectral imagery and plant measurements was performed when imagery was collected within 2 days of plant biomass sampling. Overall the 1998 imagery resulted in a better ability to predict in-season plant biophysical characteristics for all sampling dates compared to the 1997 growing season (Table 4). This difference could be attributed in part to the difference between years in sensor sensitivity and also biomass production. The 1998 growing season had larger differences in biomass production among the different $\mathrm{N}$ treatments compared to 1997. Biomass production decreased by $53.6 \%$ for 1998 and $32.9 \%$ for 1997 (no $\mathrm{N}$ treatment compared to the $269 \mathrm{~kg} \mathrm{~N} \mathrm{ha}^{-1}$ treatment) for the late August sampling date (Table 2). Biomass sampling data showed that the green waveband had the highest correlation coefficient for biomass and plant $\mathrm{N}$ concentration with few exceptions (Table 4). Past researchers evaluating hyper-spectral reflectance have 
Table 4. Linear correlation coefficients $\left(r^{2}\right)$ for biomass sampling, and plant $\mathrm{N}$ concentration with individual waveband and vegetation index by biomass sampling date and corresponding growth stage, Shelton, NE, 1997 and 1998.

\begin{tabular}{|c|c|c|c|c|c|}
\hline & \multicolumn{3}{|c|}{1997} & \multicolumn{2}{|c|}{1998} \\
\hline & $\begin{array}{l}17 \text { July } \\
\text { (13-V16) }\end{array}$ & $\begin{array}{l}\text { 7-Aug } \\
\text { (R2) }\end{array}$ & $\begin{array}{c}17 \text { Aug } \\
\text { (R4) }\end{array}$ & $\begin{array}{c}17 \text { July } \\
\text { (V14-R1) }\end{array}$ & $\begin{array}{c}19 \text { Aug } \\
\text { (R4) }\end{array}$ \\
\hline & & & Blue & & \\
\hline Biomass $\left(\mathrm{mg} \mathrm{ha}^{-1}\right)$ & $0.14^{\mathrm{a}}$ & $0.24^{\mathrm{b}}$ & $0.25^{\mathrm{b}}$ & $0.48^{\mathrm{b}}$ & $0.29^{\mathrm{b}}$ \\
\hline Plant N $\left(\mathrm{g} \mathrm{kg}^{-1}\right)$ & $0.26^{\mathrm{b}}$ & $0.23^{\mathrm{b}}$ & $\begin{array}{l}0.51^{b} \\
\text { Green }\end{array}$ & $0.47^{\mathrm{b}}$ & $0.38^{\mathrm{b}}$ \\
\hline Biomass $\left(\mathrm{mg} \mathrm{ha}^{-1}\right)$ & $0.16^{\mathrm{b}}$ & $0.41^{\mathrm{b}}$ & $0.52^{\mathrm{b}}$ & $0.51^{\mathrm{b}}$ & $0.65^{\mathrm{b}}$ \\
\hline Plant $\mathrm{N}\left(\mathrm{g} \mathrm{kg}^{-1}\right)$ & $0.30^{\mathrm{b}}$ & $0.56^{\mathrm{b}}$ & $\begin{array}{l}0.61^{\mathrm{b}} \\
\text { Red }\end{array}$ & $0.57^{\mathrm{b}}$ & $0.74^{\mathrm{b}}$ \\
\hline Biomass $\left(\mathrm{mg} \mathrm{ha}^{-1}\right)$ & $0.10^{\mathrm{a}}$ & $0.34^{\mathrm{b}}$ & $0.43^{\mathrm{b}}$ & $0.46^{\mathrm{b}}$ & $0.52^{\mathrm{b}}$ \\
\hline Plant $N\left(\mathrm{~g} \mathrm{~kg}^{-1}\right)$ & $0.21^{\mathrm{b}}$ & $0.19^{\mathrm{b}}$ & $\begin{array}{c}0.32^{\mathrm{b}} \\
\text { NIR }\end{array}$ & $0.47^{\mathrm{b}}$ & $0.53^{\mathrm{b}}$ \\
\hline Biomass $\left(\mathrm{mg} \mathrm{ha}^{-1}\right)$ & $0.12^{\mathrm{a}}$ & 0.09 & 0.09 & $0.21^{\mathrm{a}}$ & $0.50^{\mathrm{b}}$ \\
\hline Plant $\mathrm{N}\left(\mathrm{g} \mathrm{kg}^{-1}\right)$ & $0.18^{\mathrm{b}}$ & 0.01 & $\begin{array}{l}0.02 \\
\text { NDVI }\end{array}$ & $0.51^{\mathrm{b}}$ & $0.40^{\mathrm{b}}$ \\
\hline Biomass $\left(\mathrm{mg} \mathrm{ha}^{-1}\right)$ & $0.18^{\mathrm{b}}$ & $0.33^{\mathrm{b}}$ & $0.27^{\mathrm{b}}$ & $0.45^{\mathrm{b}}$ & $0.63^{\mathrm{b}}$ \\
\hline Plant $N\left(\mathrm{~g} \mathrm{~kg}^{-1}\right)$ & $0.33^{\mathrm{b}}$ & $0.15^{\mathrm{a}}$ & $\begin{array}{l}0.16^{\mathrm{b}} \\
\text { GNDVI }\end{array}$ & $0.52^{\mathrm{b}}$ & $0.57^{\mathrm{b}}$ \\
\hline Biomass $\left(\mathrm{mg} \mathrm{ha}^{-1}\right)$ & $0.28^{\mathrm{b}}$ & $0.44^{\mathrm{b}}$ & $0.50^{\mathrm{b}}$ & $0.47^{\mathrm{b}}$ & $0.65^{\mathrm{b}}$ \\
\hline Plant $\mathrm{N}\left(\mathrm{g} \mathrm{kg}^{-1}\right)$ & $0.49^{\mathrm{b}}$ & $0.44^{\mathrm{b}}$ & $0.44^{\mathrm{b}}$ & $0.60^{\mathrm{b}}$ & $0.62^{\mathrm{b}}$ \\
\hline
\end{tabular}

${ }^{\mathrm{a}, \mathrm{b}}$ Significant at the 0.01 and 0.05 probability levels, respectively.

found that reflectance in the green region $(500-550 \mathrm{~nm})$ was best for detecting $\mathrm{N}$ deficiencies. ${ }^{[8,16]}$

\section{Grain Yield Image Analysis}

Analysis of multi-spectral imagery for estimation of grain yield and grain $\mathrm{N}$ content was performed for all image collection dates beginning in late June and continuing until late August (four sampling dates per year extending from the vegetative through the reproductive growth stages). Generally the late June sampling date had the lowest correlation coefficient compared to later sampling dates regardless of waveband or index (Table 5). Plant growth stage at this sampling date was between V5-V7 depending on treatment. At this growth stage there was a significant amount of soil present within each pixel. This amount of soil 


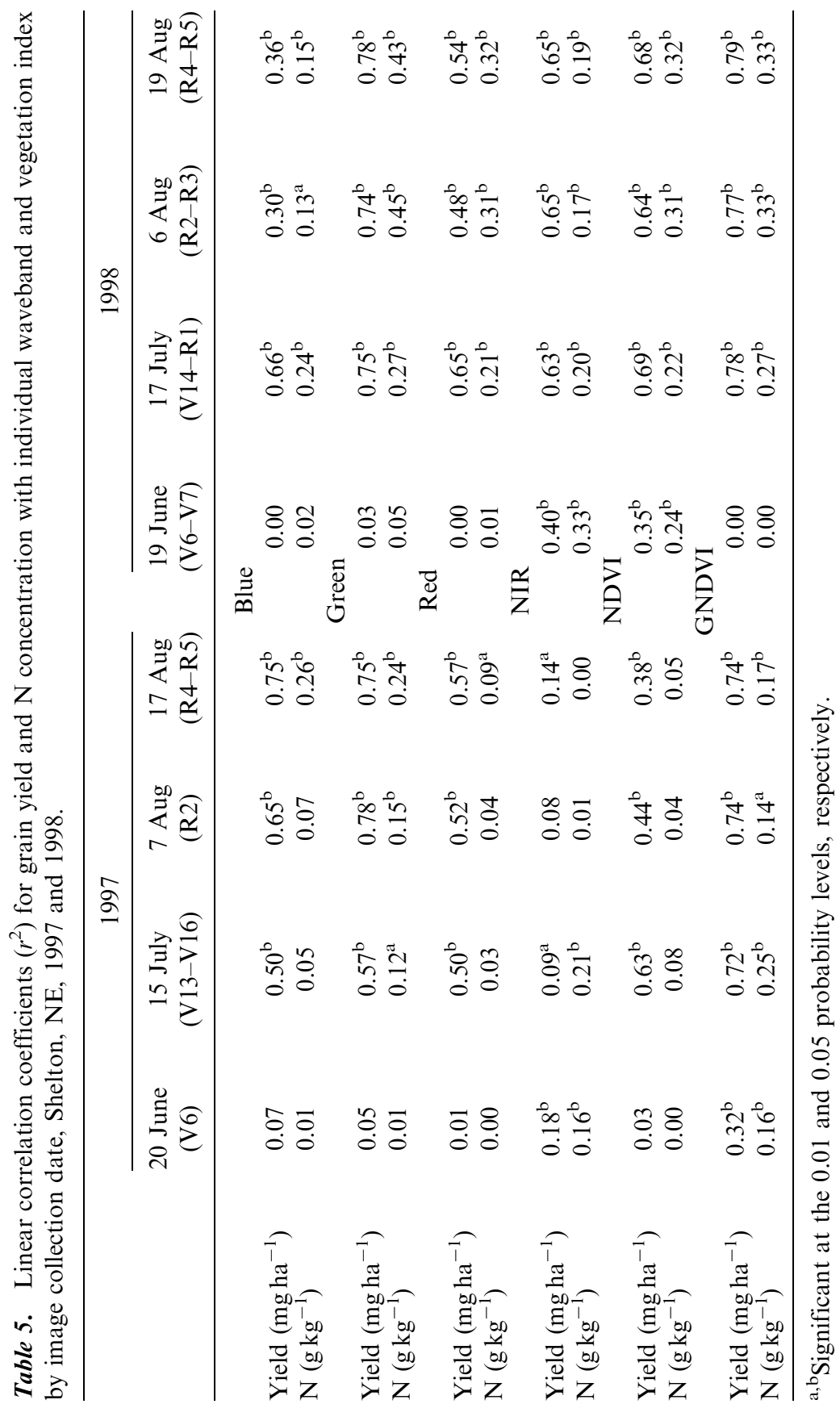


in the image contributed to the lower correlation coefficient compared to the later sampling dates when the canopy was closed.

July and August sampling in 1997 and July sampling in 1998 resulted in a significantly high correlation between grain yield and reflectance for the blue waveband (Table 5). Work by Kleman and Fagerlund ${ }^{[5]}$ noted that blue reflectance was strongly related to different irrigation levels. During the time these images were collected a drought stress occurred. The drought stress for the 1997 growing season extended from July through August, while in 1998 there was only a short time when plants exhibited visible drought stress symptoms occurring the middle of July. The drought stress was not severe enough to measure by standard methods (increased canopy temperature or neutron probe). Regression coefficients decreased substantially for the August sampling dates for 1998, following a significant rainfall event (Table 5).

Although there was significant regression coefficients with grain $\mathrm{N}$ concentration there was not any coefficients greater than 0.5 (Table 5). Similar to previous research the green waveband had the best correlation with grain $\mathrm{N}$ concentration. Blackmer et al. ${ }^{[8]}$ stated that light reflectance near $550 \mathrm{~nm}$ (green) was best for separating $\mathrm{N}$ treatment differences, and could be used to detect $\mathrm{N}$ deficiencies in corn.

Overall, images collected in 1998 had higher regression correlation coefficients for grain yield and $\mathrm{N}$ concentrations than did 1997 images (Table 5). This may be due in part to greater image sensitivity as well as increased plant response to applied $\mathrm{N}$ in 1998 compared with 1997 (Table 3). Regardless of year, the green waveband and GNDVI index had the best correlation with grain yield (Table 5). This is similar to recent results by Shanahan et al. ${ }^{[17]}$ who found that the GNDVI index obtained during midgrain field has the greatest potential of estimating grain yield.

\section{CONCLUSIONS}

In summary grain yield, plant biomass, grain $\mathrm{N}$ concentration, and plant $\mathrm{N}$ concentration were all affected by $\mathrm{N}$ rate. Overall, the 1998 imagery analysis resulted in higher regression correlation for in-season plant biophysical characteristics and grain yield compared to that for the 1997 growing season. This difference was attributed in part to the differences in sensor sensitivity, but also differences in growing season environment (rainfall) and plant response to applied nutrients. Correlations with grain yield and biomass were higher later in the growing season, once the crop canopy had closed (the late vegetative to 
reproductive growth stages). Generally the GNDVI and green waveband had the greatest correlation coefficient with grain yield.

The acceptance of remote sensing as a valid application in precision agriculture is dependent on the ability to accurately assess a given variable regardless of other factors including various nutrient and drought stresses, and/or the presence of pest pressures including weeds, insects, or diseases. This work demonstrates the ability of remotely sensed imagery to accurately estimate grain yield regardless of $\mathrm{N}$ or drought stress.

\section{REFERENCES}

1. Lillesand, T.M.; Kiefer, R.W. Remote Sensing and Image Interpretation, 2nd Ed.; John Wiley \& Sons Inc.: New York, 1987.

2. Tucker, C.J. Red and photographic infrared linear combinations for monitoring vegetation. Remote Sens. Environ. 1979, 8, 127-150.

3. Asrar, G.; Fuchs, M.; Kanemasu, E.T.; Hatfield, J.L. Estimating absorbed photosynthetic radiation and leaf area index from spectral reflectance in wheat. Agron. J. 1984, 76, 300-306.

4. Ma, B.L.; Morrison, M.J.; Dwyer, L.M. Canopy light reflectance and field greenness to assess nitrogen fertilization and yield of maize. Agron. J. 1996, 88, 915-920.

5. Kleman, J.; Fagerlund, E. Influence of different nitrogen and irrigation treatments on the spectral reflectance of barley. Remote Sens. Environ. 1987, 21, 1-14.

6. Ahlrichs, J.S.; Bauer, M.E. Relation of agronomic and multispectral reflectance characteristics of spring wheat canopies. Agron. J. 1983, 75, 987-993.

7. Aase, J.K.; Siddoway, F.H. Spring wheat yields estimates from spectral reflectance measurements. IEEE Trans. Geosci. Remote Sens. 1981, 19, 78-84.

8. Blackmer, T.M.; Schepers, J.S.; Varvel, G.E. Light reflectance compared with other nitrogen stress measurement in corn leaves. Agron. J. 1994, 86, 934-938.

9. Walburg, G.; Bauer, M.E.; Daughtry, C.S.T.; Housley, T.L. Effects of nitrogen nutrition on the growth, yield, and reflectance characteristics of corn canopies. Agron. J. 1982, 74, 677-683.

10. Aase, J.K.; Tanaka, D.L. Effects of tillage practices on soil and wheat spectral reflectance. Agron. J. 1984, 76, 814-818.

11. Blackmer, T.M.; Schepers, J.S.; Varvel, G.E.; Walter-Shea, E.A. Nitrogen deficiency detection using reflected shortwave radiation from irrigated corn canopies. Agron. J. 1996, 88, 1-5. 
12. Moran, M.S.; Pinter, P.J., Jr.; Clothier, B.E.; Allen, S.G. Effect of water stress on the canopy architecture and spectral indices of irrigated alfalfa. Remote Sens. Environ. 1989, 29, 251-261.

13. Ritchie, S.W.; Hanway, J.J.; Benson, G.O. How a Corn Plants Develops; Iowa State Univ. of Sci. and Tech. Coop. Ext. Service: Ames, IA, 1997; Spec. Pub. 48.

14. Schepers, J.S.; Francis, D.D.; Tompson, M.T. Simultaneous determination of total $\mathrm{C}$, total $\mathrm{N}$, and ${ }^{15} \mathrm{~N}$ on soil and plant material. Commun. Soil Sci. Plant Anal. 1989, 20, 949-959.

15. SAS Institute. SAS/STAT Procedures, Release 6.03 Ed.; SAS Institute: Cary, NC, 1988.

16. Everitt, J.H.; Richardson, A.J.; Gausman, H.W. Leaf reflectancenitrogen-chlorophyll relations in buffelgrass. Photogram. Engin. Remote Sens. 1985, 51, 463-466.

17. Shanahan, J.F.; Schepers, J.S.; Francis, D.D.; Varvel, G.E.; Wilhelm, W.W.; Tringe, J.M.; Schlemmer, M.R.; Major, D.J. Use of remote-sensing imagery to estimate corn grain yield. Agron. J. 2001, 93, 583-589. 


\section{Request Permission or Order Reprints Instantly!}

Interested in copying and sharing this article? In most cases, U.S. Copyright Law requires that you get permission from the article's rightsholder before using copyrighted content.

All information and materials found in this article, including but not limited to text, trademarks, patents, logos, graphics and images (the "Materials"), are the copyrighted works and other forms of intellectual property of Marcel Dekker, Inc., or its licensors. All rights not expressly granted are reserved.

Get permission to lawfully reproduce and distribute the Materials or order reprints quickly and painlessly. Simply click on the "Request Permission/ Order Reprints" link below and follow the instructions. Visit the U.S. Copyright Office for information on Fair Use limitations of U.S. copyright law. Please refer to The Association of American Publishers' (AAP) website for guidelines on Fair Use in the Classroom.

The Materials are for your personal use only and cannot be reformatted, reposted, resold or distributed by electronic means or otherwise without permission from Marcel Dekker, Inc. Marcel Dekker, Inc. grants you the limited right to display the Materials only on your personal computer or personal wireless device, and to copy and download single copies of such Materials provided that any copyright, trademark or other notice appearing on such Materials is also retained by, displayed, copied or downloaded as part of the Materials and is not removed or obscured, and provided you do not edit, modify, alter or enhance the Materials. Please refer to our Website User Agreement for more details.

\section{Request Permission/Order Reprints}

Reprints of this article can also be ordered at tp://www.dekker.com/servlet/product/DOI/101081PLN200030042 